\title{
TAXING HAZARDOUS WASTE: THE U.S. EXPERIENCE
}

\author{
Hilary Sigman ${ }^{1}$ \\ Department of Economics \\ Rutgers University
}

\begin{abstract}
Many states in the US impose taxes on hazardous waste. This paper conducts an empirical evaluation of the determinants of these taxes and reviews earlier research on their effects on hazardous waste. Earlier studies have shown that the taxes affect waste management, but my results and other evidence suggest that the tax-induced changes may not have improved welfare.
\end{abstract}

Taxes on industrial hazardous waste are one of the most extensive uses of pollution taxes in the United States. The federal government and many states governments have implemented such taxes. The diversity of hazardous waste taxes makes them an interesting example of pollution taxes because we can compare the responses of polluters to different tax regimes.

In this paper, I discuss the existing state and federal hazardous waste taxes and issues in their design and implementation. The paper then presents an empirical analysis of the tax rates adopted by states. In particular, the question is: do these taxes reflect the environmental costs of waste as opposed to other government objectives? Although an earlier study (Levinson, 2003) examines determinants of tax rates, the analysis here expands the hypothesized sources of variation and emphasizes the role of external costs. The results provide some evidence that taxes vary with environmental costs - making it possible that they improve welfare - but also point to non-environmental determinants and much unexplained variation.

I then review the literature on the empirical effects of these taxes 
on pollution and economic behavior. Studies have found only small effects of the state taxes, but these effects indicate that waste generators and managers do respond to the incentives created by taxes. The following section evaluates the advantages and disadvantages of existing taxes on hazardous waste and proposes some alternatives. A final section briefly concludes with an assessment of the U.S. experience with these taxes.

\section{Approaches to taxing hazardous waste}

Hazardous waste is a precursor to pollution, rather than a form of pollution. Wastes do not affect the environment until they are managed in some way. After a facility generates waste, it may treat it to reduce the volume or risks posed by the wastes. Some treatments, such as incineration, largely destroy the wastes, whereas other treatments, such as stabilization, merely render them safer to dispose. After any treatment, wastes are disposed, typically in specialized hazardous waste landfills. For wastewaters, facilities may also inject them into deep underground wells or release them to public water treatment works. Both treatment and disposal can take place at the facility that generates the waste or off-site, sometimes at commercial waste management facilities.

The variety of options means that there are several possible tax bases for hazardous waste taxes. One type of tax applies to substances that are precursors for hazardous waste. The federal government once used such "feedstock" taxes to help fund the Superfund program for cleanup of abandoned contaminated sites; however, these taxes expired in 1995 and have not been reauthorized.

Because they resemble conventional excise taxes, feedstock taxes are easy to administer. When a product is sold, the seller can calculate the tax due and add it to the price. Feedstock taxes are also easy to enforce because there are likely to be good records of the sale of chemicals and because conveniently few firms sell these products.

Feedstock taxes discourage use of certain products and may thus encourage facilities to reduce some wastes. For example, taxes on solvents used for cleaning metal parts may be effective in reducing the amount of solvent purchased and thus the amount of solvent that winds up as waste. However, often feedstock taxes may not be the most cost-effective tax for reducing wastes because they do not provide incentives for all possible 
practices to reduce waste or to limit the harms from waste disposal (Fullerton, 1996). Facilities may have options that divert wastes without affecting their use of the chemical, such as sending waste for recycling or reuse as fuel. They may also have alternatives to disposal, such as incineration, that can have lower environmental costs for certain wastes.

Although feedstock taxes alone do not create incentives to reduce waste generation or to alter waste management methods, a policy that rebates some or all of the tax for desirable waste management would provide these incentives. These combined policies are discussed in the section on assessment of hazardous waste taxes below.

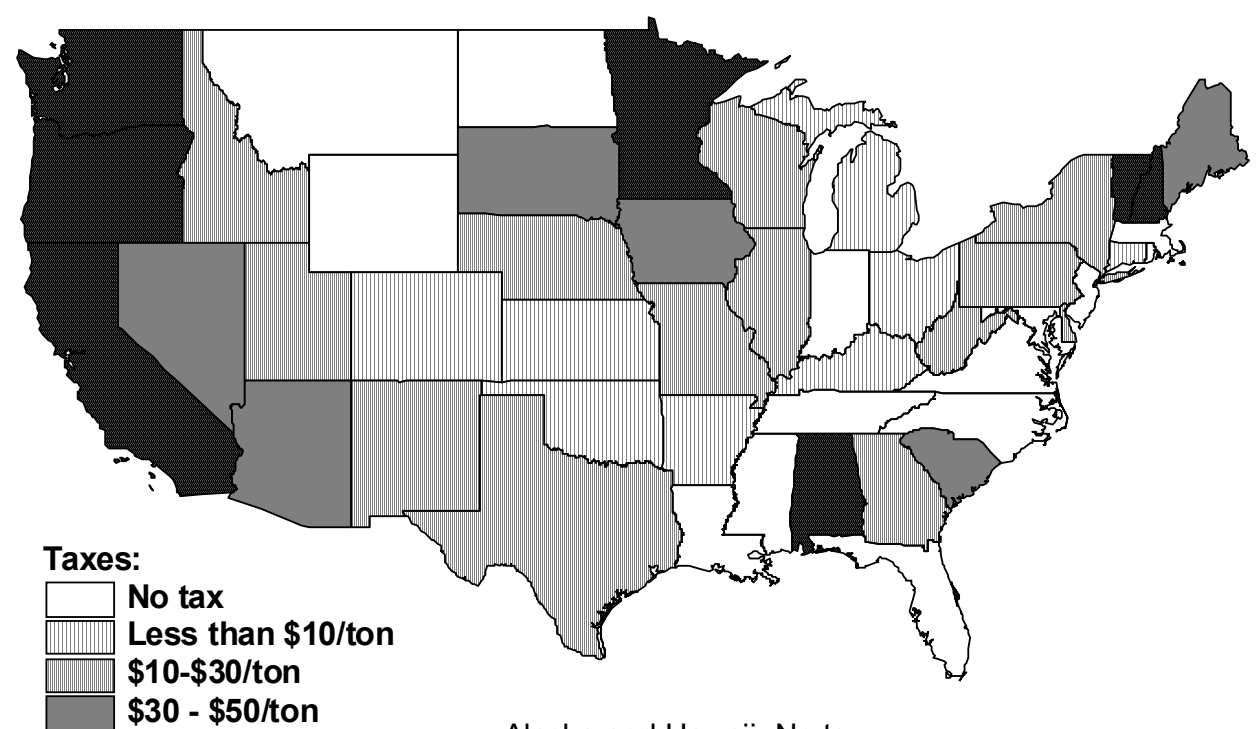
$\$ 30-\$ 50 /$ ton More than $\$ 50 /$ ton $\quad$ Alaska and Hawaii: No tax

Figure 1: Taxes on disposal in 1997

The principal alternative to a feedstock tax used in practice in the United States is a "waste-end tax." These taxes are levied on waste based on quantities generated or managed. The federal government briefly had a waste-end tax on the books in the early 1980s (Fullerton, 1996) and considered a broader waste-end tax that was never adopted (CBO, 1985). Many states have hazardous waste taxes in place. Figure 1 shows a map of the state tax rates on disposal in 1997, from a survey by the U.S. Army Corp of Engineers (1998). The state tax rates range from nothing to over 
$\$ 100 /$ ton in a few states. ${ }^{2}$

Waste-end taxes have several advantages over feedstock taxes. First, unlike feedstock taxes, they provide incentives for plants to use all possible approaches to reduce their waste. Second, they offer the flexibility of varying the tax with the management method. For example, if disposal damages the environment more than incineration does, the waste-end tax may be set at higher levels for disposal. Many states differentiate the tax based on the management method, with lower fees for incinerated (and sometimes recycled waste) than for disposed wastes. Several states, including Alabama and Michigan, restrict the tax base to wastes that are disposed in landfills.

States differentiate along other dimensions as well. Some states, for example Alabama and California, differentiate according to types of waste, charging special rates for extremely hazardous wastes. Mining wastes, which are exempt from federal hazardous waste regulation, and PCBs are among the most frequently distinguished types of waste.

Georgia, Kansas, Maine and New York subject on-site management to lower rates (Ohio taxes only off-site management). Nationally, 77\% of wastes were managed on-site in 1999 (EPA, 2001). Whether on-site waste management should be encouraged is an open question. Although on-site management reduces the risks from waste transportation, it may also increase risks if the government has a harder time ensuring regulatory compliance with on-site waste management or if scale economies allow safer management at commercial facilities.

A final dimension along which states differ is in their treatment of out-of-state waste. Differences arise through several mechanisms. Some states use generated waste as the tax base, which exempts imported waste from taxes. ${ }^{3}$ Connecticut, which has a tax on generation, explicitly adds a tax on imported waste, but Georgia does not.

Some states charge higher rates for out-of-state wastes (Levinson, 1999a). In 1992, the Supreme Court ruled that an Alabama tax was a restraint of trade in violation of the Interstate Commerce Clause of the U.S. Constitution. Alabama charged $\$ 112$ per ton on out-of-state waste and $\$ 40$ per ton on in-state waste. Nonetheless, several states continued to levy higher fees on out-of-state waste in 1997. Finally, states create difference in their in-state/out-of-state rates by setting taxes on out-ofstate rates equal to the higher of the state's own rate and the rate in the 
state of origin.

\section{The determinants of state hazardous waste taxes}

States have chosen varied rates for their hazardous waste taxes. Understanding the motivation for these choices may help to evaluate the effects of the taxes in practice and factors that will affect pollution tax adoption in other contexts. There are several motivations that may underlie state taxes.

Hazardous waste taxes may be set to correct externalities, as an economist would recommend. If so, variations in the taxes reflect differences in the external environmental costs of waste management across the country. Geographic differences in costs arise from several factors. The population exposed to hazardous releases from waste management probably varies across states, both because of differences in average population densities and in the location of population relative to waste sites. Different preferences in the exposed population might also play a role, with some communities more willing to bear costs to avoid environmental risk than others.

Environmental differences across states are another source of cost differences. Land disposal may cause less damage to the environment in more arid areas because there is less risk that contaminants seep into groundwater. It could be more costly in places with greater reliance on groundwater for drinking water, agriculture, and other uses.

Differences in regulatory stringency are a third source of geographic differences in the external costs of waste management. Most regulation of the hazardous waste occurs under the auspices of the federal Resource Conservation and Recovery Act (RCRA), which sets standards for hazardous waste management and restricts land disposal of untreated wastes. Despite the uniform standards that RCRA seems to impose, states undertake most of the implementation (permit writing), monitoring, and enforcement under RCRA (Sigman, 2003). States may use this power to tailor the effective stringency of the federal program to their own objectives.

However, variation in environmental costs may not fully explain the patterns of state taxes. A second determinant of the level of the taxes may be revenue needs. The taxes are often used to fund state programs 
for clean-up of contaminated sites, so-called state "superfunds" for sites not cleaned up under the federal Superfund program. One might thus expect high rates in states with a large number of contaminated sites awaiting cleanup. Two states set tax rates based on revenue targets by construction: West Virginia and Wisconsin do not specify a tax rate, but provide a formula that depends on total state waste generation. However, no state explicitly links the taxes to the funds needed for contaminated site cleanup.

Finally, taxes may result from competition among states. Levinson (2003) posits that states set hazardous waste tax rates as part of a "raceto-the-top," in which states set high rates to shift the environmental costs of hazardous waste management to other states. ${ }^{4}$ States that place higher taxes on out-of-state wastes are engaged in destructive competition because a welfare-maximizing national government would not base taxes on the state in which the waste originates. Levinson runs regressions in which a state's tax is determined by weighted averages of other states' tax. He uses two sets of weights: one based only on distances between the states and one based on the extent of their trade (which may be endogenous to tax rates, but more accurately captures the state's true competitors). Using the distance-based weights, he finds an elasticity of .9 during the period after the Supreme Court decision of 1992 (which precluded higher rates for out-of-state wastes), indicating a nearly one-forone response to competitors' tax rates.

\section{Explanatory variables}

In this paper, I conduct a simple empirical assessment of these hypotheses, using data on the level of state taxes on disposal in 1997. Levinson (2003) conducts the only prior study of the determinants of state tax rates. His study includes several state characteristics in addition to the competition variables, but these are not chosen to identify external environmental costs specifically (for example, he does not include groundwater use or regulatory stringency) or other hypotheses such as revenue needs. ${ }^{5}$ Thus, although his study is far preferable to this study for addressing the issue of competition, there remains a need for research on other influences on tax rates.

A few explanatory variables are used to capture possible determinants of tax rates. Summary statistics for the tax rate and these explanatory variables are shown in the second and third columns of Table 1. 
Several variables reflect variation in environmental costs across states. State average population density measures exposure to wastes. The share of the population that belongs to a conservation group represents the strength of aversion to this exposure. For other geographic differences in the costs of waste management, I use average annual rainfall and total groundwater withdrawals. ${ }^{6}$

As a summary measure of regulatory stringency (and thus the extent to which environmental costs are already internalized), I use the ratio of average expenditures of waste management by manufacturing firms to manufacturing value added in the state in $1992 .{ }^{7}$ Abatement costs are commonly used as a measure of variation in stringency, but are a flawed measure because they may also vary with the industry mix and the age of capital in the state. Levinson (2001) created an index of abatement cost variability that corrects for industry mix (at the two-digit SIC level), but it includes all pollution control costs, not just those for waste. Because air and water pollution abatement costs are the majority of abatement costs, they may swamp the variation in waste costs. Thus, the equations use unadjusted abatement costs for waste, rather than Levinson's index.

The state's revenue needs are captured by the number of contaminated sites the state lists as needing attention (Environmental Law Institute, 1998). As mentioned above, two states explicitly tie tax rates to an aggregate revenue target. So, there is no question that revenue requirements influence rates in these two states. Instead, the question in the empirical analysis is a compound question: whether revenue needs play a role for the remaining states and whether the size of the hazardous waste program is a determinant of those revenue needs. If states do choose their requirements based on a revenue target, but this target does not vary with the size of their hazardous waste cleanup program, we will see no effect.

Finally, competition is measured by the weighted average of other states' tax rate, with the squared distance between the states as the weights. This measure of competition is one of those tested by Levinson (2003).

The dependent variable is the state's tax on in-state disposal. Because 11 states in the dataset have no taxes, the estimated equations use a Tobit specification. Alaska and Hawaii are dropped to avoid unduly influencing the tax competition results, as are 4 states without state 
superfund site counts (Idaho, Indiana, North Dakota, and Wyoming,) resulting in 44 states in the analysis.

Table 1: Summary statistics for variables and Tobit estimates of determinants of state tax rates

\begin{tabular}{|c|c|c|c|c|}
\hline \multirow[b]{2}{*}{ Variable } & \multicolumn{2}{|c|}{$\begin{array}{l}\text { Summary } \\
\text { statistics }\end{array}$} & \multicolumn{2}{|c|}{ Tobit estimates } \\
\hline & Mean & $\begin{array}{l}\text { Standard } \\
\text { deviation }\end{array}$ & $\begin{array}{l}\text { Estimated } \\
\text { coefficient }\end{array}$ & $\begin{array}{c}\text { Standard } \\
\text { error }\end{array}$ \\
\hline State tax rate (per ton) in 1997 & 27.9 & 42.0 & \multicolumn{2}{|c|}{ (Dependent variable) } \\
\hline $\begin{array}{l}\text { Population density } \\
\text { (per square mile) }\end{array}$ & 353 & 1282 & $-.155^{*}$ & .051 \\
\hline $\begin{array}{l}\text { Groundwater use } \\
\text { (billon gallons/day) }\end{array}$ & 1.54 & 2.57 & $7.57^{*}$ & 2.07 \\
\hline $\begin{array}{l}\text { Rainfall } \\
\quad \text { (inches per year) }\end{array}$ & 36.1 & 14.0 & .339 & .526 \\
\hline $\begin{array}{l}\text { Conservation group members } \\
\text { (per thousand) }\end{array}$ & 8.53 & 3.62 & $8.19 *$ & 1.75 \\
\hline $\begin{array}{l}\text { Waste management costs/ } \\
\text { Manufacturing value added (\%) }\end{array}$ & .221 & .142 & .791 & 44.1 \\
\hline State superfund sites & 1571 & 2358 & .0045 & .0038 \\
\hline $\begin{array}{l}\text { Other states' taxes } \\
\text { (distance weighted) }\end{array}$ & 13.0 & 7.4 & .138 & 1.22 \\
\hline Constant & - & - & -53.4 & 34.1 \\
\hline
\end{tabular}

Notes: 44 states in the analysis.

Pseudo R squared: .09.

* indicates statistically significant at $5 \%$. 


\section{Results}

The results in Table 1 present only partial support for environmental costs as determinants of tax rates. The tax rates are statistically significantly higher in states with higher conservation group membership, consistent with this hypothesis. More strikingly, disposal tax rates are higher in states with high groundwater use, suggesting groundwater protection as a motivation for the taxes. However, rainfall does not appear to influence tax rates. Rainfall may not be that important to environmental damages with modern landfill designs.

The coefficient on population density is statistically significant with the opposite of the expected sign. It indicates lower rates in states where exposure to wastes would seem to be greatest. Perhaps states with high population density have less commercial waste management capacity. In these states, less waste arrives from out-of-state and the burden of any tax imposed falls relatively more on in-state waste generators. Bearing more of the burden may encourage states to select low taxes.

The measure of regulatory stringency (waste management operating costs as a share of manufacturing value added) does not enter the equation with a statistically significant coefficient. There are several possible reasons for the lack of an estimated effect. First, there are the problems with this variable as a measure of regulatory stringency discussed above. Second, omitted variables that tend to increase the state's choice of tax rate may also tend to increase its chosen stringency. The resulting positive correlation may mask the tradeoff between taxes and regulatory stringency in any given state. Finally, the stringency measure could respond to the tax rate because the tax avoidance that facilities practice in high tax states also may raises reported abatement costs, which again could counteract a tradeoff between taxes and regulation. However, the taxes are very small relative to overall waste management costs, so this endogeneity may not be that great in practice.

I also do not find evidence that the size of the state's cleanup program influences its choice of tax rates. States may use other revenue sources for cleanup programs, including both other hazardous waste taxes and general revenues. In particular, many states levy fixed fees on facilities that do not depend on the volume of waste managed (and thus have limited incentive effects). Thus, the distribution of taxes may reflect differences in how states choose between fixed fees and taxes, rather than 
the effect of spending on cleanup.

Finally, there is no evidence of interstate competition in tax rates. However, as mentioned above, the single cross-section here should yield to the panel data analysis in Levinson (2003), which does find effects of other states' taxes.

It is worth noting that the equation explains only a small percentage of the variation in state taxes. It is possible that the factors considered do explain a large share of the variation, but my proxies do not adequately capture them. One problem common to all the external cost variables is the use of state-level variables, which do not represent the variety of conditions within a state. For example, average population densities do not reflect exposures near waste management facilities. However, the failure to explain more of the variation could also indicate a significant role for political and institutional factors not considered here in determining the geography of tax rates.

\section{The empirical effects of hazardous waste taxes}

The variation in state hazardous waste taxes creates an opportunity to study the behavioral effects of these taxes. Studies have looked at how the variation in these rates across states affects several different choices made by waste generators.

I have explored the effects of the taxes on generation and management of a common group of wastes, spent solvents from cleaning and degreasing metal products (Sigman, 1996a). According to my research, state taxes reduce the amount of these wastes that manufacturing facilities generate. The estimated reduction is small, between 5 and $12 \%$, but the taxes are usually low compared to management costs.

In addition, existing taxes affect the management methods that firms employ. In particular, most states tax land disposal more heavily than other forms of waste management. My research suggests that these taxes do shift waste away from land disposal, causing an 11 to 44\% decline, depending on the estimate. These figures may be obsolete, however. Beginning in 1986, the federal government began to phase-out land disposal of untreated waste. Thus, the state taxes may have had a much smaller effect recently because federal regulations preclude most 
land disposal.

Other studies have examined the effect of state hazardous waste taxes on where waste is managed. Large amounts of waste cross state lines: in 1999, 5.7 million tons of hazardous waste was exported to a state different from the one in which it was generated, $70 \%$ of the total waste that was shipped at all in that year (EPA, 2001). Thus, many firms may consider multiple states as recipients of their waste and be sensitive to costs such as the taxes in those states.

Levinson (1999a, 1999b) studied the influence of these taxes on interstate shipment of waste. He finds that high taxes significantly deter waste disposal in that state. The coefficients correspond to a price elasticity of demand for waste disposal in a state of -1.1 to -1.5, indicating an elastic response. Alberini and Frost (1999) also examine the effects of taxes and other waste management costs in the state, especially costs resulting from the liability regime. They find that both land disposal and incineration respond negatively to tax rates in the state.

Whether this response to taxes is desirable depends on the determinants of tax rates. If states choose taxes that reflect environmental costs, interstate shipment in response to differential taxes reduces the environmental costs of waste management. The evidence above that tax rates may vary with waste management costs would support the view that these responses are not entirely wasteful. However, much of the variation in tax rates is not explained by costs. Thus, the taxes may give rise to unnecessary costs due to needless transportation of waste and disposal in locations where the true social cost is relatively high. ${ }^{8}$

Taxes may also affect the environment through indirect effects on waste generators' production decisions. In Sigman (1996b), I examined the effects of state hazardous waste taxes on manufacturing firms' air emissions of the solvents mentioned above. I found evidence that air emissions might rise with higher tax rates: as firms control their hazardous waste, they may substitute releases of pollution into the air. This finding illustrates the need for consistent environmental taxes across environmental media to assure that improvements in one medium do not come at too great a cost to other environmental media.

\section{An assessment of hazardous waste taxes}


Waste-end taxes have substantial advantages over traditional public policies for hazardous waste, such as those embodied in the federal RCRA program. They provide incentives for facilities to reduce waste generation by the most cost-effective means for their specific production process. Such flexibility provided by incentive-based environmental policy is always important, but may be especially important in the context of hazardous wastes because of the tremendous range of substances and production processes is involved. Even the cleverest and best-financed traditional regulator would be hard pressed to identify the lowest cost technologies for waste reduction for such a wide range of industrial processes.

The taxes provide incentives to use waste management methods with low environmental costs, but with a "safety valve" when costs are high. A generator has the option of paying the tax and using environmentally-costly management methods, such as land disposal, when it finds cleaner management methods very costly for its specific circumstances. ${ }^{9}$ By contrast, current federal hazardous waste regulation has a blanket prohibition on land disposal of untreated wastes. The benefits of eliminating land disposal may have merited the costs for some easily treated wastes, but costs are far in excess of benefits for many other types of wastes (Sigman, 2000). Taxes would provide a more nuanced approach in which some of these high cost wastes could continue to be land disposed.

Finally, if structured appropriately, hazardous waste taxes may help prioritize risks across different kinds of wastes. A waste-end tax could create many tiers of wastes based on their chemistry and thus their environmental hazards. ${ }^{10}$ Traditional command-and-control policies, with their focus on standards requiring the "best" technology, make it difficult for regulators to send clear signals about which waste streams should be preferred from an environmental perspective. Current U.S. regulations for waste generators do provide incentives to substitute wastes for which the required control technologies are less costly; these wastes may also tend to have lower environmental costs, but there is no necessary association.

However, even the best waste-end taxes are imperfect in several ways. First, although better than feedstock taxes, they are still several steps removed from the behaviors that actually damage the environment. A better approach would be to tax not waste but the contaminants released to the environment from waste management. For example, taxes 
should be levied on air emissions from incinerators and groundwater releases from landfills. Taxes on environmental releases could entirely replace existing hazardous waste policy, including not only state wasteend taxes, but also the current federal regulations that set standards for treatment, storage, and disposal of hazardous wastes.

Such taxes on environmental releases do have the disadvantage that they are more difficult to enforce than both taxes on hazardous waste generation and the current regulations. To collect these taxes the government would need to monitor air emissions and discharges into groundwater and surface water. Monitoring air and surface water releases could require costly equipment, but is probably feasible for most pollutants. Monitoring releases to groundwater, however, is trickier. Although it is possible to sample groundwater and detect contamination, isolating the facility that is the source of release and quantifying the amount released (as would be necessary for a tax) often stretches current scientific understanding. As a result, enforcement of these taxes is likely to be imperfect, weakening their influence. Even with spotty enforcement, however, taxes might send a clearer signal to polluters than current regulations.

Second, one must ask whether the incentives to control waste created by taxes are desirable given the other regulations and costs of waste management. Waste management is subject to extensive regulations under the federal RCRA program, which imposes the standards on management facilities and land disposal restrictions mentioned above. There are no estimates of the costs that RCRA adds to each ton of waste managed, but commercial waste management prices, especially for incineration, increased dramatically after the beginning of RCRA regulation (Sigman, 2000).

In addition to the costs of regulation, hazardous waste management entails substantial legal liability costs. Lawsuits may come from individuals who experience harm. In addition, the government can sue under the RCRA Corrective Action program to force facilities to pay for clean-up of environmental contamination. The EPA estimates that Corrective Action will cost $\$ 18.7$ billion dollars (in discounted 1992 dollars) over the life of the program, so the expected liability costs could be significant (EPA, 1993).

If the expected costs from liability and regulation are at least as high as the environmental costs of the release, then there is no need for a 
tax on top. Facilities already spend money to avoid regulatory and liability costs, so additional spending in response to the taxes may be excessive. Alberini and Frost (1999) and Alberini and Bartholomew (1999) show significant effects of liability on waste management decisions, indicating substantial resources already devoted. It is likely that no additional increase in the costs of hazardous waste management is desirable in the current legal and regulatory environment.

The final limitation of waste-end taxes is the incentive they create for illegal disposal of waste. Although few environmental taxes are easy to enforce, taxes on waste pose a particular problem because waste generators can easily move waste off-site before releasing it to the environment, an activity known as "midnight dumping." By raising the costs of legal waste management options, taxes may encourage this behavior.

Two studies provide empirical evidence of this response. In Sigman (1998), I study dumping of used oil, a hazardous waste commonly generated by households and small businesses. ${ }^{11}$ I find that state policies that increased the costs of managing these wastes by banning land disposal substantially increased the frequency of dumping. Fullerton and Kinnaman (1996) study the effect of a policy analogous to a waste-end tax on ordinary household waste. When the town of Charlottesville, VA imposed a charge for garbage disposal, Fullerton and Kinnaman suspect that at least of $5.3 \%$ households began dumping or burning wastes. The waste reduction from this suspected illegal behavior account for $28 \%$ of the total reduction in garbage that Fullerton and Kinnaman estimate as a response to the charge. With a sufficiently large increase in illegal disposal in response to a tax, the tax might be counterproductive because illegal disposal damages the environment much more severely than legal waste management does.

However, replacing the waste-end tax with a tax and subsidy combination, such as a deposit/refund, would solve this problem (Dinan, 1993; Fullerton and Kinnaman, 1995; Palmer and Walls, 1997). The tax/subsidy combination needed here is an example of the "two-part instruments" proposed by Fullerton and Wolverton (1999) to replace pollution taxes that pose particular monitoring or enforcement problems.

Deposit/refunds are currently used in several areas of waste management. Under "bottle bills," many states collect deposits from consumers and rebate the deposit when the consumer returns the 
container to a collection center. Several countries and U.S. states also place these deposit/refunds on household hazardous wastes, such as automobile batteries, tires, and used oil (Sigman, 1995; Stavins, 2003). A deposit/refund can mimic a waste-end tax, without the incentive for illegal disposal. The net tax is paid only by those who do not manage their waste in a way that qualifies for a refund.

Implementing the deposit/refund for industrial hazardous waste requires a more complex policy than a bottle bill. The government could charge a deposit on precursors of waste, as it does with a feedstock tax. Many wastes, such as spent solvents, begin as commercial products, so levying the deposit is not difficult. Other wastes, particularly those generated by chemical manufacturing, have more distant precursors, so choosing the appropriate deposit is more complicated. The deposit would need to be a function of the input or mix of inputs that gives rise to waste.

The refund too would require adjustments to provide the right incentives to waste generators. If the inputs on which the deposit is levied may leave the facility embodied in products, the facility might receive a full rebate on the content of those products, to avoid discouraging production rather than waste. It would receive a partial rebate for recycling (where the difference between the deposit and the refund reflects the external costs of recycling) and an even smaller partial rebate for incineration, disposal, or other management methods, depending on their environmental costs. That would leave the full deposit paid only on waste that does not show up again and has presumably been dumped illegally. All refunds should depend on the hazardous content of the wastes, rather than the absolute amount of waste (including media such as water), again making implementation complicated.

Like taxes on hazardous waste, however, even this deposit/refund would not replace the current standards for treatment, storage, and disposal facilities. To replace these standards would require incentives to reduce releases at the waste management facility. A modified deposit/refund could accomplish this goal, while maintaining the deposit/refunds' desirable effects on enforcement. Under this modified policy, the government would charge a deposit, but rebate it indirectly through subsidies to waste management facilities per unit they reduced their environmental releases. 


\section{Conclusion}

Taxes on hazardous waste have probably been a mixed blessing in the United States. Empirical evidence suggests that they have successfully reduced waste generation and reliance on land disposal. They have also altered the geography of waste management. Thus, the experience with these taxes demonstrates the ability of environmental taxes to alter polluters' behavior.

Nonetheless, the taxes may not have improved welfare. Regulations and legal liability may already internalize the environmental costs of waste management (and probably even over deter this activity). As a result, the additional incentives to reduce waste created by taxes may be undesirable. The empirical evidence suggests that external costs only partly explain the variation in state taxes, so interstate shipment in response to the taxes may create a net social loss. Finally, the taxes may encourage illegal disposal and thus have detrimental as well as beneficial effects on the environment. 


\section{Notes}

1 I am grateful to an anonymous review for helpful comments. My email address is sigman@econ.rutgers.edu.

${ }^{2}$ It would also be useful to know whether these taxes are high or low relative to the environmental costs of waste disposal. Unfortunately, no estimates are available of these environmental costs. The taxes are typically low as a fraction of commercial waste management costs. The average tax in 1998 of $\$ 28 /$ ton (see Table 1 ) compares to a commercial disposal cost in 1993 of $\$ 260 /$ ton (Sigman, 2000).

3 Even when generated waste is the tax base, states still sometimes differentiate based on management method. For example, Vermont charges different rates for generated waste destined to be disposed, treated, and recycled.

${ }^{4}$ The hypothesis that states set waste taxes too high differs from the usual case for interjurisdictional competition, in which states set taxes too low to avoid driving capital from the state (e.g., Wilson, 1999). The reason for the difference is that the state benefits from waste taxes by having a cleaner environment, but the costs are borne by out-of-state waste disposers. See Levinson (2003) for a more thorough explanation of the relationship of interstate competition in these taxes to the theory of fiscal federalism.

${ }^{5}$ Levinson (2003) includes some variables that might be relevant to capturing environmental costs. For example, per capita income may play a role in aversion to contamination (but also may measure the level of economic activity). He includes land prices, which do measure the cost of disposal, but its private cost, rather than the external cost we seek to measure here.

6 The sources of these data are as follows: population density in 1995 (per square mile) and rainfall (30 year average in inches per year for the largest city in the state) from U.S. Bureau of the Census (1996), groundwater withdrawals in 1995 (billion gallons per day) from U.S. Bureau of the Census (2000), and conservation group members (per thousand) from Hall and Kerr (1991).

${ }^{7}$ Pollution abatement operating costs for waste management are from the 1992 Pollution Abatement and Control Expenditures survey. Manufacturing value added is from the 1992 Census of Manufactures (reported in U.S. Bureau of the Census (1996)).

8 The claim that the equilibrium with taxes is more costly than the equilibrium without taxes assumes that variation in the social cost of waste management is captured by commercial management prices. If 
these prices do not reflect costs (for example, because of market power), there is a slight chance the taxed equilibrium could be more efficient.

9 The safety valve is helpful as long as tax accurately reflects the damages to the environment from the waste from each facility. If it does not, perhaps because some facilities have much more harmful waste or because the damages rise rapidly with the amount of waste generated by the facility, we may be better off with a policy that restricts waste quantities (Baumol and Oates, 1988).

${ }_{10}$ The desirability of allowing many different levels of tax argues against the alternative of marketable permits for hazardous waste. Markets would require a substantial number of participants for any category of waste.

11 Used oil is not classified as a hazardous waste under RCRA, but it was classified this way to avoid discouraging recycling. In terms of its environmental effects, however, it should be considered a hazardous waste. 


\section{References}

Alberini, Anna and Shelby Frost. 1999. "Forcing Firms to Think About the Future: Economic Incentives and the Fate of Hazardous Waste." University of Colorado Working Paper.

Alberini, Anna and John Bartholomew. 1999. "The Determinants of Hazardous Waste Disposal Choice: An Empirical Analysis of Halogenated Solvent Waste Shipments." Contemporary Economic Policy. 17(3): pp. 309-20.

Baumol, William J. and Wallace E. Oates. 1988. The Theory of Environmental Policy. Cambridge, UK: Cambridge University Press.

Congressional Budget Office. 1985. Hazardous Waste: Recent Changes and Policy Alternatives. Washington, DC: U.S. Congress.

Dinan, Terry. 1993. "Economic Efficiency Effects of Alternative Policies for Reducing Waste Disposal." Journal of Environmental Economics and Management. 25(3): pp. 242-56.

Environmental Law Institute. 1998. An Analysis of State Superfund Programs: 50 State Study, 1998 Update. Washington, DC: Environmental Law Institute.

Fullerton, Don. 1996. "Why Have Separate Environmental Taxes?" In Tax Policy and the Economy, Volume 10. Ed. James M. Poterba. Cambridge, MA: MIT Press, pp. 33-70.

Fullerton, Don and Thomas Kinnaman. 1995. "Garbage, Recycling, and Illicit Burning or Dumping." Journal of Environmental Economics and Management. 29(1): pp. 78-91..

Fullerton, Don and Thomas Kinnaman. 1996. "Household Responses to Pricing Garbage by the Bag." American Economic Review. 86(4): pp. 97184.

Fullerton, Don and Ann Wolverton. 1999. "The Case for a Two-Part Instrument: Presumptive Tax and Environmental Subsidy." In 
Environmental and Public Economics: Essays in Honor of Wallace E. Oates. Eds. A. Panagariya, P. Portney, and R. Schwab, Cheltenham, UK: Edward Elgar, pp. 32-57.

Hall, Bob and Mary Lee Kerr. 1991. The 1991-92 Green Index. Washington, DC: Island Press.

Levinson, Arik. 1999a. "NIMBY Taxes Matter: The Case of State Hazardous Waste Disposal Taxes,"Journal of Public Economics. 74(1): pp. 31-51.

Levinson, Arik. 1999b. "State Taxes and Interstate Hazardous Waste Shipments.” American Economic Review. 89(3): pp. 666-677.

Levinson, Arik. 2001. "An Industry-Adjusted Index of State Environmental Compliance Costs." In Behavioral and Distributional Effects of Environmental Policy. Eds. Carlo Carraro and Gilbert E. Metcalf. Chicago: University of Chicago Press, pp. 131-158.

Levinson, Arik. 2003. "Environmental Regulatory Competition: A Status Report and Some New Evidence." National Tax Journal, 56(1): pp. 91106.

Palmer, Karen and Margaret Walls, 1997. "Optimal Policies for Solid Waste Disposal and Recycling: Taxes, Subsidies and Standards.” Journal of Public Economics. 65(2): pp. 193-205.

Sigman, Hilary. 1995. "A Comparison of Public Policies for Lead Recycling.” RAND Journal of Economics. 26: 452-478.

Sigman, Hilary. 1996a. "Cross-Media Pollution: Responses to Restrictions on Chlorinated Solvent Releases.” Land Economics. 72(3): pp. 298-312.

Sigman, Hilary. 1996b. "The Effects of Hazardous Waste Taxes on Waste Generation and Disposal." Journal of Environmental Economics and Management. 30(2): pp. 199-217

Sigman, Hilary. 1998. "Midnight Dumping: Public Policies and Illegal Disposal of Used Oil.” RAND Journal of Economics. 29: pp. 157-178. 
Sigman, Hilary. 2000. "Hazardous Waste and Toxic Substance Policies." In Public Policies for Environmental Protection, Second Edition. Eds. Paul R. Portney and Robert N. Stavins. Washington, DC: Resources for the Future, pp. 215-260.

Sigman, Hilary, 2003. "Letting States Do the Dirty Work: State Responsibility for Federal Environmental Regulation." National Tax Journal. 56 (1): pp. 107-122.

Stavins, Robert N. 2003. "Experience with Market-based Environmental Policy Instruments." In Handbook of Environmental Economics. Eds. Karl-Göran Mäler and Jeffrey Vincent. Amsterdam: Elsevier Science.

U.S. Army Corp of Engineers. 1998. Report on Treatment, Storage \& Disposal Facilities (TSDF) for Hazardous, Toxic, and Radioactive Waste (HTRW).http://www.environmental.usace.army.mil/library/pubs/tsdf/tsdf.

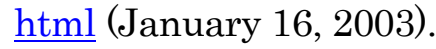

U.S. Bureau of Census. 1996. Statistical Abstract of the United States, 1996. Washington, DC: Government Printing Office.

U.S. Bureau of Census. 2000. Statistical Abstract of the United States, 2000. Washington, DC: Government Printing Office.

U.S. Environmental Protection Agency. 1993. Draft Regulatory Impact Analysis for the Final Rulemaking on Corrective Action for Solid Waste Management Units. Washington, DC: US EPA.

U.S. Environmental Protection Agency. 2001. The National Biennial RCRA Hazardous Waste Report (Based On 1999 Data). http://www.epa.gov/epaoswer/hazwaste/data/brs99/index.htm (January 16, 2003).

Wilson, John Douglas. 1999. “Theories of Tax Competition.” National Tax Journal. 52(2): pp. 269-304 